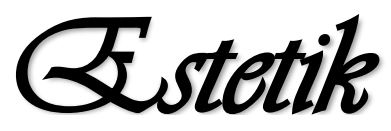

Jurnal Bahasa Indonesia
Institut Agama Islam Negeri (IAIN) Curup, Indonesia

ISSN 2622-1810 (p); 2622-1829 (e)

volume 4, number 1, 2021 | page: 1-16

DOI: http://doi.org/10.29240/estetik.v4i1.1512

\title{
Analisis Tindak Tutur Ilokusi pada Vlog Jangan Lupa Senyum Part 1 di Kanal Youtube Fiersa Besari
}

\author{
Lana Rahmasari, Asep Purwo Yudi Utomo \\ Universitas Negeri Semarang, Indonesia \\ lanarahmasari24@students.unnes.ac.id, aseppyu@mail.unnes.ac.id
}

\begin{abstract}
An illocutionary act is a speech act that is usually identified by explicit performative sentences. The research on illocutionary acts in vlogs is an action that shows the meaning of speech during communication. This study aims to describe illocutionary acts on Fiersa Besari's vlog YouTube channel Jangan Lupa Senyum Part 1 along with its speech function. The method used in this research is the descriptive method. The form of research used here is qualitative research. The data source in this study is the vlog Jangan Lupa Senyum Part 1 on the Fiersa Besari YouTube channel. The data in this study are transcripts of conversations between characters in vlogs. Data collection techniques in research using the observation method and note-taking techniques. The findings in the research in this vlog were only 15 utterances of illocutionary speech acts. From the 15 utterances, 7 data on assertive illocutionary acts, 2 directive illocutionary acts, and 7 expressive illocutionary acts. From this research, it is expected that we can understand the function of illocutionary acts that are relevant to everyday life.
\end{abstract}

Keywords: Speech Act, Ilocution, Vlog, Youtube, Fiersa Besari

Abstrak. Tindak tutur ilokusi adalah tindak tutur yang biasanya diidentifikasi dengan kalimat performatif yang eksplisit. Penelitian terhadap tindak tutur ilokusi pada vlog merupakan sebuah tindakan yang menunjukkan makna atau arti tuturan pada saat komunikasi berlangsung. Penelitian ini bertujuan untuk mendeskripsikan tindak tutur ilokusi pada vlog Jangan Lupa Senyum Part 1 di kanal youtube Fiersa Besari berserta fungsi tuturannya. Metode dalam penelitian ini adalah metode deskriptif. Bentuk penelitian yang digunakan adalah penelitian kualitatif. Sumber data dalam penelitian ini adalah vlog Jangan Lupa Senyum Part 1 di kanal youtube Fiersa Besari. Data dalam penelitian ini adalah transkrip dari percakapan antar tokoh di dalam vlog. Teknik pengumpulan data dalam penelitian menggunakan metode simak dan teknik catat. Hasil temuan dalam penelitian dalam vlog ini hanya terdapat 15 tuturan yang berjenis tindak tutur ilokusi. Dari 15 tuturan tersebut, terbagi atas 7 data tindak tutur ilokusi arsetif, 2 tindak tutur ilokusi direktif, dan 7 tindak tutur ilokusi ekspresif. Dari penelitian ini diharapkan dapat memahami fungsi tindak tutur ilokusi yang relevan dengan kehidupan sehari-hari.

Kata Kunci: Tindak Tutur, Ilokusi, Vlog, Youtube, Fiersa Besari 


\section{Pendahuluan}

Kehidupan masyarakat era globalisassi saat ini sering kali tidak dapat dijauhkan dari keberadaan media sosial. Salah satu media sosial yang kerap difungsikan oleh warga internet adalah Youtube. Di dalam Youtube banyak sekali ditawarkan jenis konten video. Konten video yang saat ini lumrah kita dijumpai di Youtube adalah vlog. Vlog (video-blogging) memanifestasikan kegiatan blogging yang dilaksanakan dengan memanfaatkan wadah video. Melalui vlog, pengguna internet dapat dengan leluasa membagikan informasi, menuangkan isi pikiran, berpendapat, maupun beropini mengenai segala hal. Dari banyaknya fenomena vlog di era saat ini, pasti ditemui penggunaan bahasa karena didalam vlog erat dengan dialog antar tokoh yang berkaitan dengan kajian pragmatik. Pragmatik ialah cabang linguistik yang mempelajari bahasa yang digunakan untuk berkomunikasi dalam situasi tertentu (Nadar, 2009: 2). Salah satu objek kajian di dalam pragmatik ialah tindak tutur.

Tindak tutur memanifestasikan sebuah keterampilan berbahasa penutur dengan tujuan khusus memaparkan atau mengkomunikasikan tafsir sekaligus maksud ujaran penutur kepada mitra tutur. Tafsir dari makna serta maksud dari sebuah ujaran dapat dimengerti dan dipahami oleh mitra tutur berlandaskan dari konteks tuturan si penutur. Leech (dalam Nadar 2009:6) mengemukakan bahwa konteks yang terpenting dalam pragmatik adalah latar belakang pemahaman yang dimiliki oleh penutur dan mitra tutur dalam membuat interpretasi mengenai apa yang dimaksud oleh penutur ketika membuat tuturan. Konteks memanifestasikan situasi sebuah komunikasi antar manusia (Sudaryat, 2009:21). Searle mengungkapkan bahwa tindak tutur boleh saja dibedakan kedalam 3 macam yaitu: 1) tuturan lokusi (locu-tionary act), 2) tuturan ilokusi (ilocutionary act), dan 3) tuturan perlokusi (perlocutionary act) (dalam Wijana, dkk, 2010: 20-26).

Tindak tutur ilokusi (The Act of Doing Something) merupakan sebuah tuturan selain untuk mengatakan atau menginformasikan sesuatu, juga dapat dipergunakan untuk melakukan sesuatu sejauh situasi tuturnya dipertimbangkan secara seksama (Wijana, 1996:18). Tindak tutur ilokusi digunakan oleh penuturnya sebagai sebuah tindakan 
menyatakan, berjanji, minta maaf, memberi saran, mengancam, meramalkan, memerintah, dan meminta. Tindak tutur ilokusi dipecah menjadi lima macam, yaitu tindak tutur direktif, tindak tutur ekspresif, tindak tutur representatif atau asertif, tindak tutur deklarasi (deklaratif).

Salah satu youtuber Indonesia yang cukup diminati konten vloggingnya ialah Fiersa Besari. Dalam kanal youtubenya yang bernama Fiersa Besari, ia menyuguhkan konten petualangan dan musik. Di dalam penelitian ini penulis memfokuskan pada penggunaan tindak tutur ilokusi di dalam vlog. Salah satu konten vlog yang sangat diminati oleh pemirsa adalah video dengan judul Jangan Lupa Senyum part 1. Vlog tersebut telah disaksikan oleh sebanyak 1,4 juta kali oleh warga internet. Sehingga tindak tutur ilokusi yang akan dikaji di fokuskan pada s vlog berjudul Jangan Lupa Senyum Part 1 pada kanal Youtube Fiersa Besari. Tindak tutur dalam vlog tersebut dapat dilihat dari aktivitas percakapan semua orang yang ada di dalam vlog tersebut.

Alasan peneliti mengambil objek penelitian tuturan dalm vlog Jangan Lupa Senyum part 1 yaitu karena video tersebut sangat diminati oleh warga internet kalangan milenial. Hal tersebut terbukti dari banyaknya viewers pada video tersebut. Salah satu kekhasan dalam video-video Fiersa Besari ialah di dalamnya selalu terselip beberapa humor. Selain itu, di dalam setiap video Fiersa Besari selalu terselip tuturan-tuturan yang mengedukasi permirsanya. Dengan begitu video pasti erat kaitannya dengan penggunaan tindak tutur. Maka dari itu, peneliti tertarik mengkaji lebih jauh mengenai jenis tindak tutur ilokusi dan fungsinya dalam tuturan para tokoh pada vlog Jangan Lupa Senyum part 1.

Terdapat penelitian yang relevan dari beberapa peneliti bahasa, antara lain peelitian yang telah dilaksanakan oleh Fenda Dina Puspita Sari (2012), yang mengkaji tindak tutur dan fungsi tuturan ekspresif dalam acara galau nite di Metro TV, Ekky Cintyaresi Sendilatta(2013) mengkaji tindak tutur pada film "Garuda di Dadaku" karya Ida Ifansyah, Isma Savanty Muwalidah (2014) mengkaji mengenai tindak tutur ilokusi dalam wacana pembaca menulis pada surat kabar Jawa Post pada edisi September 2014, Anis Nurulita Rahma (2014) mengkaji tindak tutur ilokusi dalam dialog film animasi meraih mimpi, Pezi Awram (2014) 
mengkaji mengenai tindak tutur ilokusi pada novel Negeri 5 Menara karya Ahmad Fuadi, Hatmi Farih, dkk (2014) mengkaji tindak tutur ekspresif padasegmen catatab najwa dalam acara mata najwa di Metro TV, La Ode Irman Sait (2015) yang mengkaji kalimat ilokusi dalam novel Kemamang karya Koen Setyawan, Isma Savanty M (2015) mengkaji tindak tutur ilokusi dalam wacana pembaca menulis pada Surat Kabar Jawa Pos Edisi September 2014, Elfi Suriani (2016) mengkaji mengenai tindak tutur ilokusi pada novel hafalan sholat Delisa karya Tere Liye, Julio (2016) mengkaji kategori dan fungsi tindak ilokusi dalam film TheDevil Wears Prada Karya David Frankel, Farrah Fitriah dan Siti Sarah Fitriani (2017) mengkaji mengenai tindak tutur dalam novel marwah di ujung bara karya R.H Fitriadi, Tio Novaria Sinaga, dkk (2018) mengkaji mengenai tindak tutur pada lakon sumur tanpa dasar karya Arifin C. Noer, SriMurti, dkk (2018) mengkaji tindak tutur ekspresif dalam film kehormatan di balik kerudung sutradara Tya Subiakti Satrio, dan Waidah Nasution dan Efrima (2019) mengkaji tindak tutur ilokusi dalam iklan radio 99,3 Toss FM Merduati Banda Aceh.

Dari beberapa penelitian tersebut, terdapat persamaan dan perbedaan. Persamaan yang banyak dijumpai adalah pada fokus penelitian. Semua penelitian tersebut meneliti tentang jenis tindak tutur. Meskipun demikian, hasil analisis jenis tindak tuturnya tidak selalu sama. Pada penelitian ini dikaji tuturan ilokusi secara mendetail. Penelitian ini hendaklah mampu berkontribusi sebagai pelengkap dari hasil penelitian terdahulu khususnya tentang kajian pragmatik dalam fokus tindak tutur ilokusi.

Tujuan dari penelitian ini adalah menjelaskan jenis-jenis tindak tutur ilokusi dalam tuturan tokoh di vlog Jangan Lupa Senyum Part 1. Manfaat penelitian ini adalah sebagai sumbangsih pengetahuan dari peneliti dalam bidang kajian pragmatik terkhusus dalam jenis tindak tutur ilokusi, dengan harapan agar kajian ilmu pragmatik semakin berkembang di kemudian hari. Selain itu agar masyarakat memahami jenis tindak tutur ilokusi dalam tuturan sehari-hari.

Cara kerja penelitian ini mengaplikasikan metode deskriptif di dalamnya. Lazimnya metode penelitian dimanifestasikan sebagai sudut pandang ilmiah guna mendapat data atau beberapa data dengan sasaran 
tertentu (Sugiyono, 2011:3). Uraian dari penelitian yang bersifat deskriptif ialah data-data yang ada akan diuraikan dengan kata-kata dan kalimat-kalimat tidak dalam wujud angka-angka. Data penelitian yang bermacam-macam bentuknya setelah terkumpul harus dijabarkan melalui pendeskripsian dengan sejelas-jelasnya. Sumber data pada penelitian ini diperoleh dari dialog antar tokoh dalam vlog Jangan Lupa Senyum part 1. Guna mengantongi data yang relevan, peneliti menerapkan metode simak dan teknik catat. Video yang sudah disiapkan kemudian disimak secara teliti dan berulang, kemudian dilanjutkan dengan teknik catat. Peneliti menyimak sumber data disesuaikan dengan tujuan penelitian yaitu implikatur percakapan, sedangkan yang tidak berhubungan dengan penelitian diabaikan. Ahli bahasa Mahsun dalam bukunya yang berjudul Metode Penelitian Bahasa, telah merumuskan bahwa bahan atau materi penelitian, alat, jalan penelitian, variabel, data yang hendak disediakan dan analisis data akan dicakup di dalam metode penelitian (Mahsun, 2005: 70).

Teknik cacat digunakan untuk memudahkan peneliti untuk menganalisis impikatur percakapan dan mengungkapkan permasalahan yang terdapat di dalam sumber data. Teknik catat digunakan sebagai tindakan penyediaan data dalam penelitian ini. Teknik catat dalam penelitian ini ialah menyalin tuturan yang terdapat di vlog Jangan Lupa Senyum part 1 dalam bentuk teks tertulis. Hasil yang didapat kemudian dianalisis melalui pendekatan kualitatif berdasar teori-teori mengenai tindak tutur ilokusi. Menurut Bogdan dan Taylor, penelitian kualitatif memanifestasikan strategi penelitian yang diharapkan dapat menetaskan data berbentuk tertulis maupun lisan yang berasal dari orang-orang dan perilaku yang bisa diamati (dalam Moleong, 2011: 4).

\section{Hasil Dan Pembahasan}

Hasil analisis data oleh peneliti dari penelitian ini, telah diperoleh sejumlah data dan berikut ialah penjabaran hasil analisis data.

\section{Tindak Tutur Ilokusi asertif atau Representatif}

Hasil dari penelitian ini diperoleh kategori tindak tutur ilokusi asertif. Kategori tindak tutur asertif dalam penelitian ini terdiri dari 4 
fungsi tuturan yaitu: tindak tutur ilokusi asertif menginformasikan, mengutarakan, mengklaim, dan menyatakan.

Data 1

Konteks: Fiersa Besari membuka sesi vlog sambil menyorotkan kamera kepada teman-temannya yang sedang berbenah mempersiapkan peralatan untuk mendaki.

Fiersa: "Naik gunung memang mengasikkan tapi bukan berarti kita bisa sembarangan, harus ada yang dipersiapkan bukan hanya modal keyakinan"

Kalimat tuturan diatas dituturkan kepada mitra tutur (audiens) ketika membuka sesi $\log$. Data kalimat yang dituturkan Fiersa tersebut tergolong tuturan ilokusi asertif, hal ini dikarenakan data tuturan diatas menginformasikan dan menyatakan kepada audiens bahwa kegiatan mendaki gunung merupakan kegiatan yang mengasikkan, kalimat tersebut juga memiliki maksud lain agar ketika audiens (mitra tutur) melakukan hal yang disarankan penutur. Yaitu ketika hendak mendaki gunung segala sesuatu perlengkapan mendaki dipersiapkan semaksimal mungkin, tidak hanya bermodalkan yakin dan niat saja. Hasil penelitian ini senada dengan analisis penelitian terdahulu yang telah dirampungkan oleh La Ode (2015:5) pada data kalimat: "Susah menjelaskannya. Itu semacam makhluk halus. Banyak orang disini melihatnya." Wujud ilokusi dalam kalimat di atas ialah tindak tutur ilokusi asertif dengan sifat mengklaim. Dari hasil penelitian La Ode tersebut maksud dalam data kalimat tersebut ialah: (a) memberitahukan suatu cerita kepada mitra tutur, (b) sebuah bentuk ungkapan agar mitra tutur berhati-hati karena apa yang mereka lihat adalah hantu. Kesamaan keduanya adalah penutur sama-sama menyatakan suatu hal yang dipahaminya. Namun perbedaannya adalah pada penelitian yang dilakukan ole La Ode, menyebutkan adanya klaim yang belum tentu dapat dibuktikan kebenarannya.

Data 2

Konteks:

Fiersa: "Oh iya jarak dari Bandung ke Purwakarta itu sekitar 2 jam kurang kalau kita ngebut. Kami tiba di Purwakarta sekitar jam 8 lebih langsung menghampiri Manji dan timnya di depan minimartket." 
Data tuturan pada data nomor 2 termasuk dalam kategori tuturan asertif, dapat dilihat dari penggunaan bahasa penutur yang menginformasikan bahwa saat menempuh perjalanan dari Bandung ke Purwakarta hanya memakan waktu 2 jam kurang jika ngebut. Kalimat tuturan tersebut juga memiliki fungsi memberitahukan kepada audiens jika rombongan mereka berangkat menuju purwakarta sekitar pukul 06.30. Hasil penelitian ini secorak dengan hasil penelitian terdahulu yang dilaksanakan Pezi Awram (2014). Dalam data: Gedung utama di pondok ini dua. Pertama adalah Masjid Jami' dua tingkat berkapasitas empat ribu orang. Di sini semua murid shalat berjamaah dan mendalami Al-Quran. Di sini pula setiap Kamis, empat ratusan guru bertemu mendiskusikan proses belajar mengajar,".... (N5M: halaman 31). Persamaan penetitian ini dengan penelitian yang dilakukan oleh Pezi Awram adalah bentuk kalimat yang termasuk dalam tuturan ilokusi asertif atau representatif dengan tujuan menginformasikan kepada mitra tutur.

Data 3

Konteks: Fiersa menjelaskan alasanmemilih mendaki Gunung Lembu

Fiersa: "Iya kita akan mendaki Gunung Lembu, kenapa Gunung Lembu? Karena saya sendiri saya tidak yakin apakah manji akan kuat atau tidak jika diberi gunung yang langsung berat."

Data kalimat nomor 3 tergolong dalam tindak tutur ilokusi asertif, selain bertujuan menginformasikan tuturan Fiersa tersebut juga meminta agar mitra tutur Anji sanggup menyelesaikan pendakian ke Gunung Lembu ini. Hasil analisis data ini serupa dalam penelitian Ekky Cintyaresi (2013) yan tercantum pada data:

Bayu :"Hmm gini , gue mau numpang latihan bola disini".

Zahra :"Latihan bola?".

Persamaan dengan penelitian tersebut yaitu tindak tutur asertif dengan tujuan mengutarakan maksud kepada mitra tutur.

Data 4

Konteks: Fiersa menceritakan pengalamannya kepada para audiens. 
Fiersa: "Saya pribadi pun sudah tiga kali naik ke gunung lembu, dan seingat saya trek gunung lembu itu terbilang santai, ketinggiannya hanya sekitar 700 mdpl tidak terlalu tinggi tapi disaat yang sama memiliki keindahan di bagian batu lembunya."

Data kalimat tuturan Fiersa Besari nomor 4 termasuk kategori tindak tutur ilokusi asertif, tuturan tersebut memberikan pernyataan mengenai pengalamannya sudah tiga kali melakukan pendakian ke Gunung Lembu, serta menginformasikan bahwa walaupun ketinggian Gunung Lembu hanya 700 mdpl gunung ini tetap memiliki keindahannya tersendiri yang terletak di bagian batu lembu, sehingga secara tidak langsung penutur menyarankan untuk mitra tutur mencoba mendaki Gunung Lembu. Hal ini serupa pasa penelitian La Ode (2015:5) pada kalimat"Ada cahaya di kejauhan. Kami mengikutinya sampai kemari." Kategori tindak tutur ilokusi pada data dalam penelitian ini dan pada penelitian yang dilakukan oleh La Ode ialah tindak tutur ilokusi asertif yang berwujud pernyataan. Namun bedanya pada jurnal La Ode tersebut tidak membuat lawan tuturnya melakukan sesuatu seperti halnya tuturan pada penelitian ini.

\section{Data 5}

Fiersa: "Menyadari hari masih siang dan mengingat perjalanan ke atas puncak lembu hanya memakan waktu 2-3 jam kami pun bersantai di basecamp.."

Kalimat tuturan nomor 5 berkategori tindak tutur ilokusi asertif, tuturan tersebut menginformasikan kepada audiens bahwa perjalanan menuju puncak Gunung Lembu tidak memakan waktu yang lama. Kalimat tersebut juga berfungsi memyarankan agar tidak perlu tergesa-gesa ketika melakukan pendakian di Gunung Lembu, karena Gunung Lembu bukan gunung yang terlalu tinggi dan menantang. Analisis data ini serupa dalam dengan hasil penelitian Pezi Awram (2014) pada tuturan "Kami punya kompetisi sepakbola yang ketat dan diadakan sepanjang tahun. Semua pertandingan bahkan selalu dilengkapi komentator langsung yang menggunakan bahasa Inggris dan Arab," kata Burhan dengan penuh semangat menunjuk lapangan dan gedung besar seperti hanggar. Kalimat tuturan tersebut memiliki fungsi untuk menginformasikan sesuatu kepada mitra tutur. 


\section{Data 6}

Konteks: Fiersa membagikan informasi kepada audiens.

Fiersa: "Belakangan saya tahu bahwa trek ini bernama sedong asmiran dan memang trek baru, trek ini dibuat lebh menantang, lebih menukik dan rasa-rasanya jaraknya sama panjangnya dengan trek asli."

Penggalan kalimat tersebut masuk ke dalam kategori tindak tutur ilokusi asertif. Dapat dilihat bahwa penutur menginformasikan gambaran jalur pendakian di Gunung Lembu yang bernama Sedong Asmiran. Fungsi dari kalimat tersebut adalah menginformasikan kepada mitra tutur perihal trek pendakian. Tuturan ini juga memiliki fungsi untuk mengingatkan agar mitra tutur tidak menganggap ringan sebuah kegiatan pendakian karena trek yang akan kita lalui bisa saja berubah. Hal ini secorak dengan hasil analisis dalam penelitian terdahulu yang dilaksanakan oleh Pezi Awram (2014) pada tuturan “... Gedung ini seukuran hampir setengah lapangan sepakbola dan di ujungnya ada panggung serta tirai pertunjukan.Tampak mukanya minimalis dengan gaya Art-Deco, bergaris-garis lurus. Sederhana tapi megah. Di atas gerbangnya yang mengahadap keluar tergantung jam antik dan tulisan dari besi berlapis krom..".(N5M: halaman 32). Hanya perbedaannya terletak pada fungsi tuturan, jika dalam penelitian ini data tuturan 6 berfungsi untuk menginformasikan dan memberi himbauan berbeda. sedangkan data yang dipaparkan Pezi berfungsi hanya untuk menginformasikan saja kepada mitra tuturnya.

\section{Data 7}

Konteks: Fiersa menanyai Anji perihal latar belakangnya memilih jurusan sastra mandari saat kuliah.

Fiersa: "Tapi kenapa? maksudnya awal... ah masuk sastra mandarin ah, itu karena apa? Apa karena nonton film kungfu apa gimana?"

Anji : "Engga engga karena peluang kerjanya masih lebih besar dibandingkan yang lain pada saat itu, tahun 97 aku masak kuliah, udah tua juga berarti."

Kalimat tuturan Anji di atas masuk ke kategori tindak tutur ilokusi asertif dikarenakan ujaran tersebut menginformasikan bahwa peluang kerja lulusan Sastra Mandarin masih sangat besar pada saat tahun 1997. Kalimat tersebut juga berfungsi menyatakan bahwa Anji sendiri sudah 
tidak muda lagi. Hal ini secorak dalam hasil analisis penelitian yang telah dilakukan oleh Julio (2016) dalam data "Engkau tahu, saya tidak akan selamanya dimodeling". Persamaan yang ditemukan adalah tuturan ilokusi asertif dengan fungsi menyatakan sesuatu.

\section{Tindak Tutur Ilokusi Direktif}

Hasil dari analisis yang telah peneliti lakukan, ditemukan kategori tindak tutur ilokusi direktif. Ditemui 3 fungsi tuturan ilokusi direktif pada penelitian ini yaitu tindak tutur ilokusi direktif mengarahkan, menuntun atau menyarankan.

Data 8

Konteks: Anji menjawab pertanyaan Fiersa Besari perihal media sosial.

Anji: "IG adalah tempat untuk berbagi foto dari hp gitu, tapi sekarang bisa digunakan untuk akun jualan, untuk berpromosi dan sangat power full. Dulu FB juga untuk dikampus doang. Tapi sekarang bisa begitu powerfullnya, tik tok udah bisa membuktikan itu dengam mempopulerkan banyak lagu, di Indonesia aja kaya misal lagu lagi syantiknya Siti Badriah jelas dari tiktok dan itu menjadi lagu dengan views terbanyak di youtube Indonesia. Dan terus yang baru baru ini yang--entah apa yang merasukimu, nah iyakan gitu gitukan, tapi lagu itu jadi naik garagara tiktok. Lalukanlah apa yang lo lakukan di instagram di facebook di youtube ditiktok, karena kita gatau suatu hari mungkin tiktok bisa menjadi sebuah aplikasi yg sangat powerfull mengalahkan instagram"

Data kalimat nomor 8 tergolong dalam kategori tindak tutur ilokusi direktif, tuturan tersebut menginformasikan serta memaparkan pengetahuan yang dimiliki oleh penutur kepada mitra tutur. Tuturan tersebut juga berfungsi untuk menuntun mitra tutur agar bersedia mengikuti perkembangan zaman untuk menjajal media kreatif tik-tok. Hal tersebut secorak dengan sebuah analisis yang telah dilakukan oleh Pezi Awram pada tahun 2014. ..."Jadi Amak minta dengan sangat waang tidak masuk SMA. Bukan karena uang tapi supaya ada bibit unggul yang masuk madrasah aliyah."... (N5M: halaman 8).

Data 9

Konteks: Fiersa besari dalam vlognya berbagai tips dan pengalamannya naik ke Gunung Lembu. 
Fiersa: “... nah tapi ingat kalau kawan-kawan ke Gunung Lembu lewat jalur manapun, masalah di gunung ini adalah monyet. Monyet disini sudah terbiasa diberi makan oleh wisatawan, jadi mereka terbiasa merebut makanan dari kita. Lengah sedikit langsung ambil, waduh bahaya sekali, makanya kalo ke hutan atau ke gunung jangan terbiasaa memberi makanan kepada hewan, ya kecuali hewannya ambil sendiri kaya dua kali tuh saya kena serangan babi, huh dasar tuh babi babi."

Data kalimat tersebut berkategori tindak tutur ilokusi direktif karena bermaksud menginformasikan dan berfungsi untuk menginstruksi atau mengarahkan para audien untuk berhati-hati dan tidak merusak ekosistem alam dengan cara memberi makan hewan liar. Analisis data ini ssecoral dengan sebuah penelitian terdahulu oleh Wahidah Nasution dan Efrima (2019: 266) dalam data:

Karyawan : ya ampun, makanya bu pakai pulpen boldiner pro

Tuturan data karyawan berkategori tindak tutur direktif dengan fungsi menyarankan, penggalan kalimat tersebut dituturkan karyawan kepada mitra tutur manajer dengan tujuan menyarankan si manajer agar menggunakan merk pulpen tertentu. Kesamaan analisis data pada data nomor 9 secorak dengan penelitian Wahidah Nasution dan Efrima adalah bahasan utama mengenai topik tindak tutur ilokusi direktif dengan tujuan sama-sama memiliki fungsi untuk menyarankan tindakan kepada mitra tutur.

\section{Tindak Tutur Ilokusi Ekspresif}

Berdasarkan hasil pengamatan peneliti, ditemukan kategori tindak tutur ilokusi ekspresif yang setelah didalami kembali terdiri dari satu fungsi tuturan yaitu tindak tutur ilokusi ekspresif memuji atau fungsi menyenangkan.

Data 10

Konteks: Fiersa Besari menjelaskan latar belakang melakukan kegiatan

Fiersa:"Maka ketika ada seorang, eh dia youtuber, musisis atau apa ya? Ah, maka ketika ada seorang pesohor mangajak saya naik gunung saya penasaran apakah dia kuat melakukan pendakian tau akan menyerah ditengah jalan? Mari kita buktukan." 
Data tindak tutur diatas termasuk dalam tindak tutur ilokusi ekspresif, tuturan pada data nomor 10 bertujuan untuk memuji, atau membanggakan seseorang yang dalam konteks di tujukan kepada Anji karena sangat terkenal dan namanya diketahui oleh banyak masyarakat. Hal ini secorak dengan sebuah analisis yang telah dilakukan oleh Hatmi Farih, dkk (2014:3) pada data kalimat: "Bukan pesohor yang kita cela, tapi partai yang malas bekerja." Tindak tutur ekspresif yang berwujud literal dan langsung dalam data tersebut ditandai oleh tuturan bukan pesohor yang kita cela. Namun terdapat perbedaan yang terletak pada fungsi tuturannya. Data dalam penelitian Analisis Tindak Tutur Ilokusi pada vlog berjudul Jangan Lupa Senyum Part 1 pada kanal Youtube Fiersa Besari ini berkategori tindak tutur ilokusi ekspresif yang fungsi untuk menyanjung atau membanggakan seseorang, sedangkan data tindak tutur ekspresif yang diteliti oleh Hatmi Farih, dkk berfungsi sebagai ungkapan rasa kecewa penutur kepada beberapa partai politik.

\section{Data 11}

Konteks: Fiersa Besari memperkenalkan tiga temannya sembari menyorotkan kamera kepada satu persatu temannya.

Data: "Orang-orang yang saya ajak nih, yang kemarin menemani ke Gunung Sumbing, ada Ucen si koki handal, ada Pawas yang memang ukhtiukhti bertanya nih ini siapa nih mirip anggota smash dan ada Oki Sulistiyawati."

Data kalimat pada data nomor 11 termasuk kategori tindak tutur ilokusi ekspresif, tuturan tersebut memiliki maksud memuji mitra tutur yang ditujukan kepada mitra tutur Ucen yang pandai serta rajin memasak sewatu melakukan pendakian dan Pawas yang berparas menawan sehingga diidolakan oleh para audiens wanita.

\section{Data 12}

Konteks: Fiersa menjelaskan alasan mengajak ketiga sahabatnya.

Fiersa: "Nah kenapa tiga orang sahabat saya ini yang saya ajak, pertama ucen karena dia jago masak waktu digunung sumbing juga dia yg terusterusan masak, dia masak tanpa disuruh dan dia masak dengan suka hati, ya sudah lah senang sekali kan kami." 
Data berupa penggalan kalimat pada data nomor 12 berkategori tindak tutur ilokusi ekspresif, dikarenakan di dalam tuturan Fiersa tersebut bermaksud ungkapan rasa senang karena Ucen bersedia menjadi juru masak saat kegiatan pendakian ini.

\section{Data 13}

Konteks: Fiersa menjelaskan alasan mengajak ketiga sahabatnya.

Fiersa: "Kedua kenapa Eki? Tidak perlu dijelaskan lagi, kalo dia memang lord, meskipun sosoknya abstrak tapi dia memberikan keberuntungan."

Data berupa penggalan kalimat nomor 13 tergolong ke dalam jenis tindak tutur ilokusi ekspresif dengan alasan selain bermaksud mengkritik Eki yang pembawaannya abstrak atau tidak jelas tingkah lakunya, tuturan tersebut juga memiliki fungsi memuji sang mitra tutur Eki sebagai sososk yang selalu membawa keberuntungan.

\section{Data 14}

Konteks: Fiersa menjelaskan alasan mengajak ketiga sahabatnya.

Fiersa: "Satu orang lagi pawas, kenapa kamii mengajak paswa? Karena diantara kami bertiga hanya pawas yang bisa menyetir keluar kota tanpa mengantuk. Dan pawas juga tampangnya lumayan lah, ganteng jadi untuk kalian penonton cewe mungkin akan bertahan melihat Pawas."

Tuturan pada data kalimat nomer 14 termasuk dalam kategori tindak tutur ilokusi ekspresif, tuturan pada data 14 bermaksud menjelaskan alasan penutur mengajak Pawas. Tuturan tersebut juga berfungsi untuk memuji mitra tutur "Pawas" yang memiliki kemampuan menyetir ke luar kota tanpa mengantuk serta tampangnya yang ganteng. Data tuturan nomer 14 tersebut bukan bertujuan untuk membual maupun berpura-pura, melainkan untuk memberikan informasi yang setakar dengan fakta. Analisis data tersebut sesuai dengan pendapat yang dikemukakan oleh Chaer (2010:29). Chaer mengatakan bahwa tindak tutur ekspresif memuji merupakan sebuah ujaran yang timbul akibat berkenaan dengan beberapa faktor. Faktor yang berkaitan dengan tindak tutur ekspresif diantaranya: pertama, disebabkan oleh kondisi petutur setara dengan kenyataan, kedua karena adanya tujuan ingin menyenangkan hati lawan tutur, ketiga karena adanya keinginan 
melegakan hati lawan tutur, dan keempat karena adanya perilaku terpuji atau membanggakan yang dilakukan petutur.

Kalimat tuturan pada data 11,12,13, dan 14 ini secorak dengan penelitian Sri murti, dkk (2018:29) dalam data:

Ifan : "Mbak cantik ya. Saya foto boleh nggak saya wartawan loh nanti saya masukin ke majalah saya. Hmm okay. Mbak mengapa terlihat tegang? Apa saya aneh? Anggap saja saya ini teman lama, karena kita bertemu Uma sekali ini saja"

Syahdu (lawan tutur dari penutur Ifan) memiliki wajah yang cantik, sehingga Ifan (petutur) menuturkan tuturan ekspresif memujinya.

Data kalimat pada penelitian Sri Murti, dkk diatas secara tidak langsung membuat lawan tuturnya merasa tersanjung, senang, dan bangga karena dipuji.

Data 15

Konteks: Anji menceritakan pengalamannya sembari menjawab pertanyaan Fiersa Besari.

Anji: “...ku pernah baca buku seni untuk bersikap bodo amat dan itu bagus banget bukunya."

Kalimat tuturan diatas termasuk dalam tindak tutur ilokusi ekspresif karena menginformasikan kepada audiens bahwa buku dengan judul Sebuah Seni untuk Bersikap Bodoamat adalah buku yang bagus, selain itu tuturan tersebut juga berfungsi untuk memerintah agar audiens membaca buku tersebut. Analisis data ini secorak dengan hasil penelitian Pezi Awram (2014). Hal tersebut dapat dilihat dari data: Pak Sutan terdiam dan sejenak raut muka berubah-ubah "Wah lebih bagus lagi itu," jawabnya malu-malu dengan suara rendah. Persamaan yang dapat dilihat adalah fungsi tuturan yang digunakan untuk memuji sesuatu.

\section{Kesimpulan}

Dari hasil analisis jenis tindak tutur ilokusi, dapat diketahui bahwa pada vlog Jangan Lupa Senyum part 1 di kanal youtube Fiersa Besari terdapat sejumlah 15 tuturan yang berjenis tindak tutur ilokusi. Dari sejumlah 15 data tuturan dalam penelitian ini, terbagi atas 2 data yang 
tergolong tindak tutur ilokusi direktif, 6 data yang tergolong tindak tutur ilokusi ekspresif, dan 7 data yang tergolong tindak tutur ilokusi asertif.

Berdasarkan hasil penelitian, peneliti akan mengemukakan beberapa saran, yaitu (1) hasil penelitian mengenai tindak tutur ilokusi pada vlog Jangan Lupa Senyum part 1 di kanal youtube Fiersa Besari diharapkan dapat memperluas wawasan pembaca yang bersinggungan dengan macam-macam tindak tutur, terkhusus pada tindak tutur ilokusi, (2) hasil temuan jenis tindak tutur ilokusi dapat memberikan kontribusi pengembangan ilmu pengetahuan dalam nidang pragmatik, (3) bagi pengamat lain, diharapkam hasil penelitian ini dapat menjadi sumber rujukan untuk penelitiannya. Peneliti berharap penelitian pragmatik di masa mendatang, khususnya mengenai jenis tindak tutur ilokusi bisa lebih baik dan lebih mendalam.

\section{Bibliografi}

Awram, Pezi. 2014. "Analisis Tindak Tutur Ilokusi pada Novel Negeri 5 Menara karya Ahmad Fuadi”. Skripsi. Universitas Bengkulu.

Chaer, Abdul. 2010. Kesantunan Berbahasa. Jakarta: PT Rineka Cipta.

Fitriah, Farrah dan Siti Sarah Fitriani. 2017. "Analisis Tindak Tutur dalam Novel Marwah di Ujung Bara Karya R.H Fitriadi”. Master Bahasa Vol. 5 No. 1; Januari 2017:51-62.

Indramadani, H.F, dkk. 2014. "Tindak Tutur Ekspresif Pada Segmen Catatan Najwa Dalam Acara Mata Najwa Di Metro TV". Jurnal. Universitas Jember.

La Ode Irman Sait. 2005. "Kalimat Ilokusi dalam Novel Kemamang karya Koen Setyawan”. Jurnal Humanika No. 15, Vol. 3, Desember 2015 / ISSN 1979-8296. (2015).

Mahsun. Metode Penelitian Bahasa. Jakarta: PT Raja Grafindo.

Moleong, L.J. 2011. Metodologi Penelitian Kualitatif Edisi Revisi. Bandung: PT. Remaja Rosdakarya.

Murti, Sri, dkk. 2018. "Tindak Tutur Ekspresif Dalam Film Kehormatan di Balik Kerudung Sutradara Tya Cubiakto Satrio". Jurnal. STKIP PGRI Lubuklinggau.

Muwalidah, Isma Savanty. 2015. "Analisis Tindak Tutur Ilokusi dalam Wacana Pembaca Menulis pada Surat Kabar Jawa Pos Edisi 
September 2014". Artikel Publikasi. Universitas Muhammadiyah Surakarta.

Nadar, F. X. 2009. Pragmatik dan Penelitian Bahasa. Yogyakarta: Graha Ilmu.

Nasution, Waidah dan Efrima. 2010. "Analisis Tindak Tutur Ilokusi Dalam Iklan Radio 99,3 Toss FM Merduati Banda Aceh". Jurnal. STKIP Bina Bangsa Getsempena.

Rahma, A. N. 2014 "Analisis Tindak Tutur Ilokusi dalam Dialog Film Animasi Meraih Mimpi”. Jurnal Skriptorium, 2(2), 13-24.

Sari, Fenda Dina P. 2012. "Tindak Tutur dan Fungsi Tuturan Ekspresif dalam Acara Galau Nite di Metro TV: Suatu Kajian Pragmatik". Jurnal Skriptorium, Vol. 1 No. 2 Tahun 2012. 1-14.

Sendilatta, E.C. 2013. "Analisis Tindak Tutur Pada Film "Garuda di Dadaku" Karya Ifa Ifansyah". Jurnal. SMA Tarakan.

Sinaga, Tio Novaria, dkk. 2018. "Analisis Tindak Tutur pada Lakon Sumur Tanpa Dasar Karya Arifin C. Noer”. Jurnal. FKIP Untan.

Sudaryat, Y. 2009. Makna dalam wacana (prinsip-prinsip semantik dan pragmatik). Bandung: Yrama Widya.

Sumurung, J.B. 2016 "Kategori dan Fungsi Tindak Ilokusi Dalam Film The Devil Wears Prada Karya David Frankel (Suatu Analisis Pragmatik)". Jurnal Skripsi. Universitas Sam Ratulangi.

Suriani, Elfi. 2016 "Analisis Tindak Tutur Ilokusi pada Novel Hafalan Sholat Delisa karya Tere Liye". Skripsi. Universitas Maritim Ali Haji Tanjungpinang.

Sugiyono. 1996. Metode Penelitian Pendidikan, "Pendekatan Kualitatif, Kuantitatif $R \& D^{\prime \prime}$. Bandung: Alfabeta.

Wijana, I Dewa Putu. 1996. Dasar-dasar Pragmatik. Yogyakarta: Penerbit Andi.

Wijana, I Dewa Putu dan Muh Rohmadi. 2010. Analisis Wacana Pragmatik: Kajian Teori dan Analisis. Surakarta: Yuma Pustaka. 